\title{
Connectivity among jaguar populations in the Sierra Madre Oriental, México
}

\author{
Gmelina Dueñas-López ${ }^{1}$, Octavio C. Rosas-Rosas ${ }^{2 *}$, Leonardo Chapa-Vargas ${ }^{3}$ Louis C. Bender $^{4}$, Luis Antonio Tarango- \\ Arámbula$^{2}$, Juan Felipe Martínez-Montoya² and José Luis Alcántara-Carbajal ${ }^{1}$
}

\footnotetext{
${ }^{1}$ Colegio de Postgraduados, Campus Montecillo. Carretera México-Texcoco, Km. 36.5, Montecillo, 56230 Texcoco, Estado de México, México. Email: gmelina.dl@gmail.com (GD-L), jlalcant@colpos.mx (JLAC).

${ }^{2}$ Colegio de Postgraduados-Campus San Luis Potosí. Iturbide \#73. Salinas de Hidalgo, S.L.P. 78621. México. Email: octaviocrr@ colpos.mx (OCR-R), Itarango@colpos.mx (LAT-A), fmontoya@colpos.mx (JFM-M).

${ }^{3}$ Instituto Potosino de Investigación Científica y Tecnológica A.C. Camino a la Presa San José No.2055, Lomas 4 a Secc. San Luis Potosí 78216.San Luis Potosí, México. Email: Ichapa@ipicyt.edu.mx (LC-V)

${ }^{4}$ Extension Animal Sciences and Natural Resources, New México State University, Las Cruces, New México, U.S.A. Email: Ibender@ nmsu.edu (LCB)

*Corresponding author
}

Introduction: The jaguar (Panthera onca) is an apex carnivore that is vulnerable to habitat fragmentation, and some of its populations are believed to be isolated in México where it is classed as endangered. The main the objective of our study was to evaluate connectivity of available jaguar habitat from the Sierra Madre Oriental of México (SMO) towards southern México.

Methods: We determined least-cost pathways for jaguar movements among habitat patches in the SMO and identified potential corridors from the SMO. We used recent jaguar presence data and maximum entropy modeling to identify habitat patches in the SMO. We then used the Analytical Hierarchy Process to generate input values for a resistance (landscape permeability) matrix for jaguar movements that we generated using Multi-Criteria-Evaluation with a weighted linear combination. We then modeled least-cost pathways for both dispersal and local movements of jaguars.

Results: We identified 581 potential highly suitable habitat patches for the jaguar. Of these, three were $>100$ $\mathrm{km}^{2}$ and thus met the criteria for fundamental (i. e. capable of supporting a viable jaguar population) patches. The resistance matrix contained $3 \%$ of low cost and $49 \%$ intermediate cost areas for jaguar movements. Least-cost pathways analysis showed 61 dispersal routes totaling $>2,000 \mathrm{~km}$ and $>200$ travel routes, with the largest number of both route types in Hidalgo. We also identified potentially five significant corridors for jaguar movement within the SMO and south towards southern México populations.

Discussion and implications: We determined that the SMO contains significant jaguar habitat with multiple biological corridors for connectivity with more southern populations of jaguar in México. Based on this, we recommend development of management strategies to facilitate exchange of individuals from the SMO with other known jaguar populations in southern states (i. e. Oaxaca, Tabasco, Guerrero). Principal strategies may focus on habitat management of fundamental patches and habitat restoration between or around stepping-stones. Promoting connectivity among patches and populations which inhabit the SMO will increase its potential as a biodiversity conservation area.

Key words: Biodiversity, corridors, habitat fragmentation, jaguar, least-cost pathways, movements 


\section{Introduction}

Biological corridors are important to connect populations that would otherwise be isolated, and thus mitigate the effects of fragmentation, one of the main threats to biodiversity (Bennett et al. 2004). Corridors are generally identified from spatial analyses in combination with inferences about movement patterns (i. e. "functional corridors") and habitat requirements (i. e. "structural corridors"; Cushman et al. 2009).

Large carnivores often function as keystone species in terms of their value for wildlife conservation. When extirpated, ecosystem functions may be destabilized and ecosystems could be driven to a disturbance state (Cramer and Portier 2001). The jaguar (Panthera onca) is an apex predator with a historical distribution that ranged from the southern United States to the Río Negro in Argentina and included much of México (Seymour 1989). Presently, the distribution of the jaguar in México is much reduced as compared to its historic range (Sanderson et al. 2002). Moreover, due to its large home range, this species is susceptible to the influences of habitat fragmentation (Dixon et al. 2006). Therefore, it is considered endangered in México (Semarnat 2010).

The Sierra Madre Oriental (SMO), the eastern mountain range of México, has been classified as having only medium priority for the long-term conservation and viability of the jaguar in México (Sanderson et al. 2002). This classification was given because the SMO was considered isolated from the rest of the distributional range of jaguars in México (Rabinowitz and Zeller 2010). However, recent studies indicate that the SMO may have significant potential for the conservation of jaguars (Villordo-Galván et al. 2010; Rodríguez-Soto et al. 2011). Thus, characterizing the SMO as a region of limited conservation potential for jaguars may be premature, and could result in well-intentioned conservation priorities that may actually be detrimental for the species, as has happened to other organisms (e.g. Morrison et al. 2012). For example, we are aware of no evidence that indicates that jaguar populations in the SMO are genetically isolated from other populations, which could justify marginalization of the SMO as a viable conservation unit for jaguars in México. Because of the presence of jaguar populations in the SMO, we suggest that the SMO deserves attention to evaluate both the real status of jaguar habitat and the connectivity among populations in this region.

Distributional studies have reported jaguars in areas where they were considered extirpated, suggesting that these areas may contain habitat that could sustain the species (Sanderson et al. 2002). These studies have also identified the need to promote connectivity among these areas to increase both dispersal potential and maintenance of these populations (Grigione et al. 2009; Villordo-Galván et al. 2010; Rodríguez-Soto et al. 2011; Briones-Salas et al. 2012). This is the present case in the SMO of México. Therefore, our objectives were to (1) evaluate the current habitat conditions for jaguars within the SMO and (2) to model habitat linkages that could facilitate exchange of jaguars with established populations, particularly to the south of the SMO.

\section{Material and Methods}

Study area. The flora and fauna of the SMO are mainly of tropical origin, and the SMO in northeastern México is a key region for biodiversity conservation (Ortega-Huerta and Peterson 2004). It is located at the northern limits of low and medium tropical moist forests, as well as tropical oak (Quercus spp.) forest. Cloud forests are also present in this region. Dominant climates include warm sub-humid (AW2), sub-temperate humid (A) Cf, and temperate with continuous precipitations $C(f)$. The topography of this area range from very rugged to flat to undulating, with a of humid tropical climate. The altitude ranges from 0 to 2,300 $\mathrm{m}$ and the annual rainfall varies from 600 to 2,500mm (INEGI 2011). 
Our evaluation area was centered at $21^{\circ} 4^{\prime} 46^{\prime \prime} \mathrm{N}$ and $-98^{\circ} 47^{\prime} 8^{\prime \prime} \mathrm{W}$ and included $30,837 \mathrm{~km}^{2}$ in the southern SMO. This region includes seven priority conservation areas that are managed under different categories (Ortega-Huerta and Peterson 2004). These areas include the AbraTanchipa Biosphere Reserve which harbors one of the most important jaguar populations in the SMO (Figure 1; Villordo-Galván et al. 2010).

Increasing human populations and resultant habitat loss and increased fragmentation of remaining natural habitats is the primary threat for long term conservation of the SMO. In addition to increasing urbanization, rural areas are influenced by frequent land conversions from natural habitats to agriculture and cattle pasturing. In all cases, road development threatens the connectivity of wildlife populations and natural habitats throughout the mountain range. Numerous rural agrarian communities are found throughout the SMO, and these communities require services, environmental products, and food as they grow; this often results in overuse of the natural resources (including water, timber, forage for livestock, game, etc.) in the region. Current policies affecting habitat conservation, restoration, and management are mostly inadequate in the region, as are policies aimed at conservation of biodiversity (Villordo-Galván et al. 2010; Sahagún-Sánchez et al. 2011).

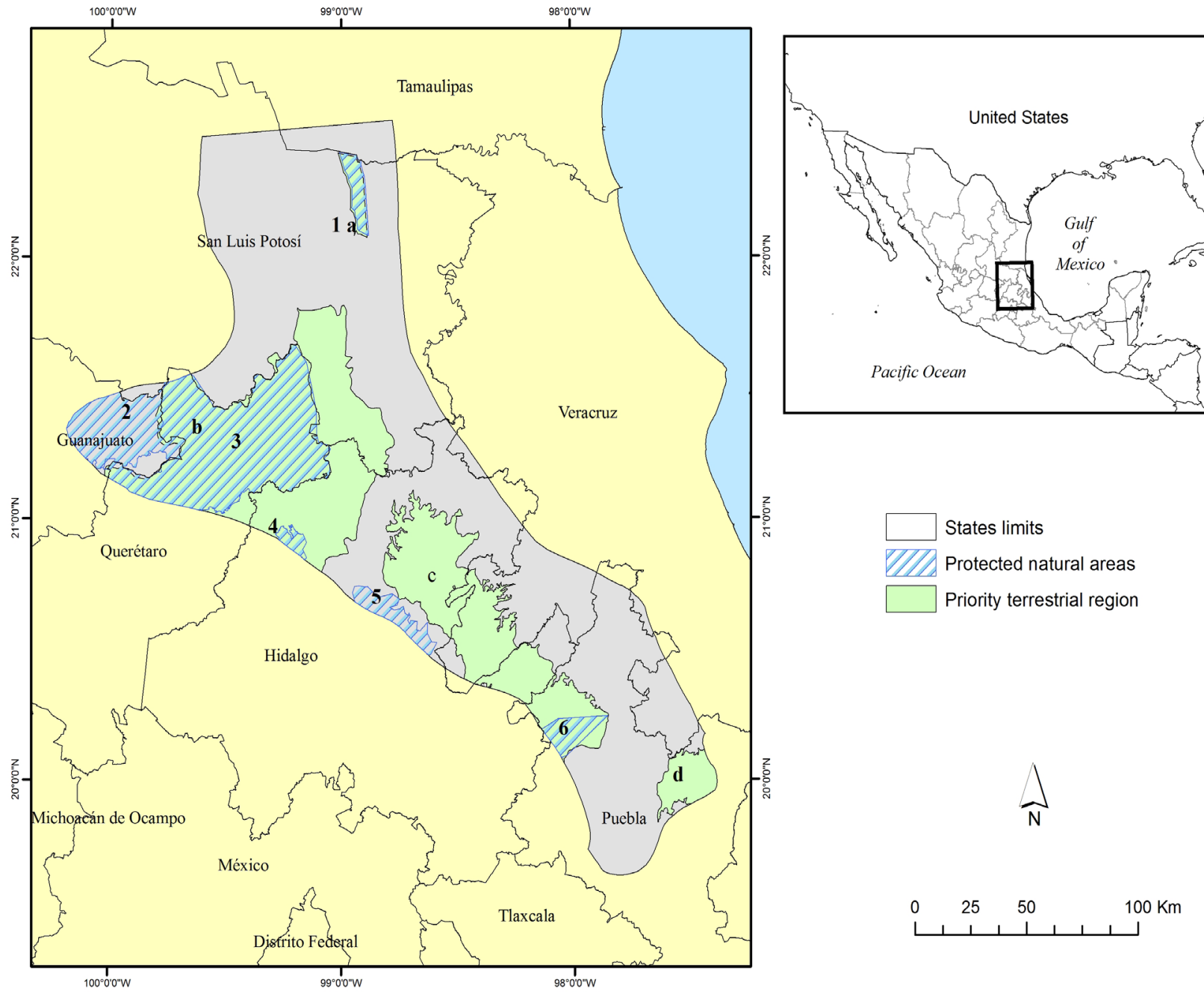

Figure 1. Evaluation area for modeling suitable habitats and biological corridors of jaguars in the Sierra Madre Oriental of México. Protected natural areas in the evaluation area include: (1) Sierra del Abra Tanchipa, (2) Sierra Gorda de Guanajuato, (3) Sierra Gorda, (4) Los Marmoles, (5) Barranca de Meztitlan, and (6) Cuenca Hidrográfica del Rio Necaxa. Priority Terrestrial Region areas in the evaluation area include: (a) Sierra del Abra Tanchipa, (b) Sierra Gorda - Rio Moctezuma, (c) Bosque Mesofilos de la Sierra Madre Oriental, (d) Cuetzalan. 
Identification of potential habitat patches. We developed a jaguar occurrence database for the SMO that included only photographic records that (1) were collected within the previous 12 years and (2) were verified as jaguars by experts. We used maximum entropy modeling (Maxent 3.3.3; Phillips et al. 2006) to predict potential jaguar habitat patches from presence records. Maximum entropy modeling uses only known locations to determine key correlates of a species presence in a region. Because it uses only presence data, Maxent eliminates the need for pseudo-absence data which can bias wildlife-habitat models and thus provides a less biased alternative to other approaches that require the generation of known non-use areas ( $i$. e. discriminant analysis, logistic regression, etc; Phillips et al. 2006; Baldwin and Bender 2008). We identified variables that likely influence jaguar presence in Mexican habitats, including elevation, slope, land use and vegetation type, distance to roads, distance to water sources, and human population density (Ortega-Huerta and Medley 1999; Monroy-Vilchis et al. 2008; Rosas-Rosas et al. 2010; Colchero et al. 2011; Rodríguez-Soto et al. 2011). We obtained baseline geospatial digital maps for these variables from INEGI ${ }^{\circledR}$ (Mexican National Institute of Statistics and Geography). Digital map resolution was $30 \mathrm{~m}$ at 1:250,000.

We modeled all possible 1-6 variable candidate models and compared resultant models using receiver operating characteristic $(\mathrm{ROC})$ plots and the critical ratio test (Pearce and Ferrier 2000 as modified by Baldwin and Bender 2008). We compared models using ROC plots to assess relative performance and to establish thresholds for identifying the likelihood of a site being occupied by jaguar (Phillips et al. 2006). We then used the area-under-the-curve (AUC) to assist in selecting the most-appropriate model (Fielding and Bell 1997; Phillips et al. 2006). AUC provides an index of accuracy of models; values range from 0.5 to 1.0 with values of 0.5 indicating no fit greater than that expected by chance alone, whereas models with AUC > 0.7 indicate good fit (Swets 1988). We used $30 \%$ of locations as test data to approximate SEs around AUC scores.

We compared all possible models, and reported models with the highest AUC value for each subset of habitat variables (i. e. 1-6 variable models). Because higher dimensioned models often have greater AUC even if some variables contribute little to the model (Baldwin and Bender 2008), we (1) used AUC to select the model with the best fit (highest AUC) from each set of 1-6 variable models (to ensure that only models that fit the data well were considered) and then (2) compared whether the highest AUC model differed statistically from lower (more parsimonious) models. If they did not differ, we selected the most parsimonious (fewer variable) model. For the latter, we used the critical ratio test (Pearce and Ferrier 2000; Baldwin and Bender 2008) to compare the highest AUC model to simpler models to determine if the increase in explanatory value was significant at $a=0.05$. We also derived thresholds for probability of jaguar presence for test data by maximizing sensitivity and minimizing specificity (Fielding and Bell 1997; Phillips et al. 2006). We used these thresholds to convert probabilities to binary response (presence-absence) and used the equal test sensitivity and specificity threshold values to calculate successful classification percentages to corroborate results from ROC curves. We corroborated model selection using concordance (percent successful classification of sites) because a model that poorly classifies the data it was built from is unlikely to have any true predictive ability (Hosmer and Lemeshow 1989).

Once a preferred model was determined, we used the binary predictions to generate a model of 2 habitat quality classifications, high (probability of jaguar presence $>0.390$ ) and low (probability of presence $<0.390$ ). We discarded low quality habitat patches and used only high quality patches in further analyses. We calculated the area of each patch in order to differentiate between fundamental patches and stepping-stone patches. Fundamental patches encompassed at least $100 \mathrm{~km}^{2}$ of optimal jaguar habitat, which was the minimal area 
reported capable of holding a population of 5 individual jaguars (Núñez-Pérez 2011). In contrast, the minimal area for a stepping-stone was $1 \mathrm{~km}^{2}$ (Bunn et al. 2000; Bennett et al. 2004).

Identification of potential corridors. We used a functional connectivity model (Rabinowitz and Zeller 2010) utilizing a least cost-path method (LCP; LaRue and Nielsen 2008) to analyze jaguar movement opportunities. This method involves analyzing landscape structure and the response of the target species to the landscape (Dickson et al. 2005; Cushman et al. 2009). The result is a parameters value matrix that reflects the difficulty or ease for jaguar movements through the landscape, termed a permeability or resistance matrix. The permeability matrix in turn allows identification of the leastcost paths of movement (Rabinowitz and Zeller 2010).

We used the same landscape characteristics described for maximum entropy modeling to evaluate landscape structure and its permeability to jaguar movements (Figure 2). However, because habitat attributes that correlate with jaguar presence may not be the same as those that facilitate or inhibit long range movements of jaguars, we used Analytical Hierarchy Analysis (AHP; Saaty 1980) to develop the landscape permeability matrix rather than the maximum entropy modeling results. AHP is a process that utilizes pair-wise comparison matrices to clarify the relative importance of criteria that measure each elements (habitat variables) contribution to movements. Experts then compare every possible pairing and enter ratings, which are based on a continuous scale of nine points (Saaty 1980). We interviewed jaguar experts to quantify how landscape characteristics may influence jaguar movements, and analyzed their responses using Expert Choice 11v (Expert Choice Inc., Pittsburgh, PA; http://expertchoice.com). We selected the interviews with the best consistency index (IC) for each criterion to develop inputs for each variable in the permeability matrix. This evaluation requires a minimum value for data acceptance of IC $<1$ (Malczewski 2004).

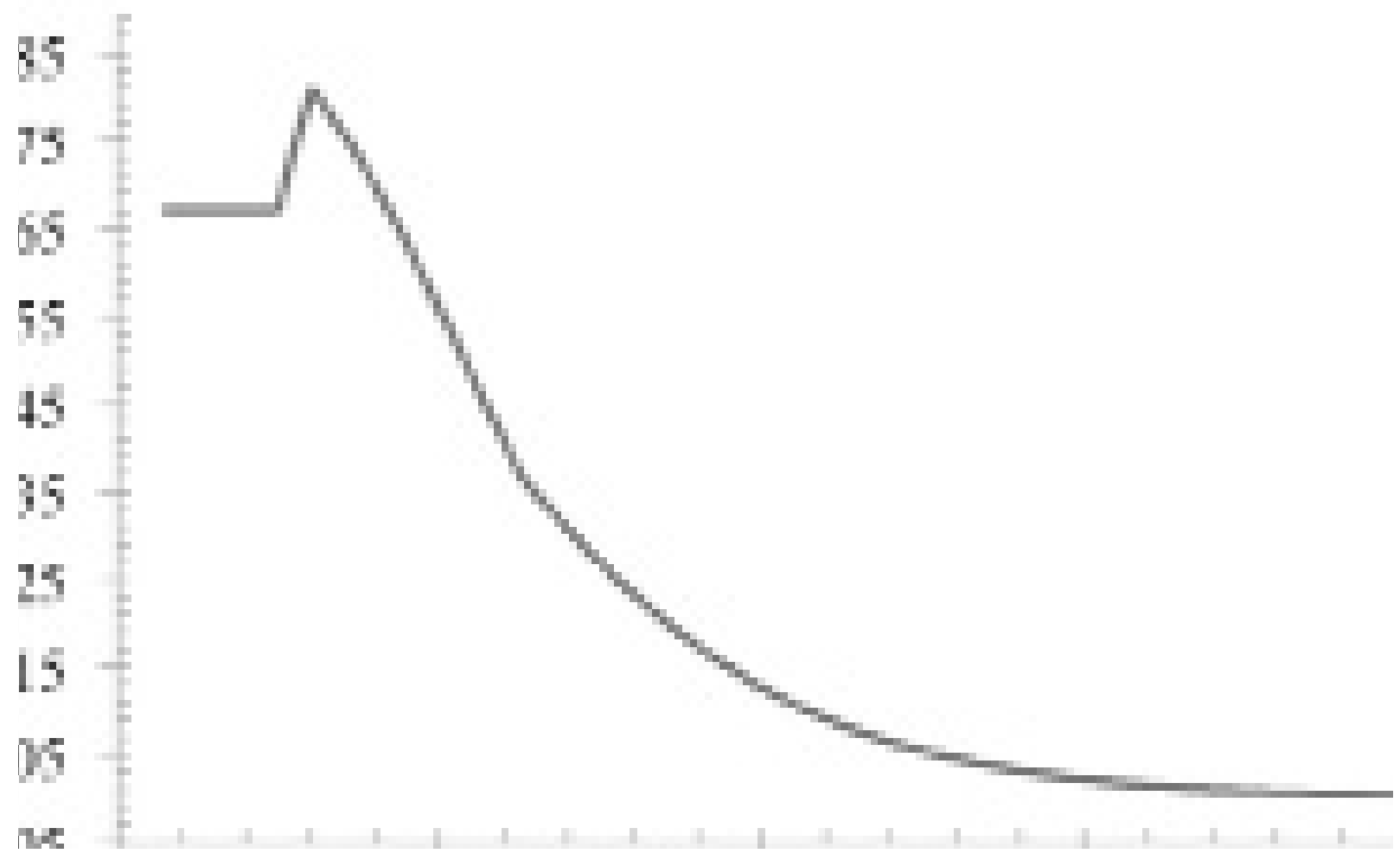

Figure 2. Hierarchical model in which the landscape habitat criteria are illustrated that define the resistance of the landscape to movements of jaguars in the permeability matrix. 
We then used the Multi-Criteria-Evaluation (MCE) module in IDRISI Andes (Eastman 2004) to assign the values derived from AHP using the Weighted Linear Combination (WCL) method (Eastman 2004). This allowed production of a raster reflecting the condition of the evaluation area with respect to the evaluated landscape elements (Malczewski 2004). The WCL is a weighted average, in which the landscape variables are input in raster format with weights assigned to each from the AHP. The decision maker directly assigns the weights of "relative importance" to each alternative by multiplying the importance weight assigned for each attribute by the scaled value given to the alternative on that attribute, and summing the products over all attributes. When the overall scores are calculated for all of the alternatives, the alternative with the highest overall score is chosen (Malczewski 2004). The output is a map of suitable habitat scaled from 0 to 1 , where $1=$ no resistance to movement. We reclassified the resultant map into 9 categories using the inverse of the score to create the permeability matrix; higher values thus indicated a major barrier to jaguar movements. We also calculated the percentage of the area occupied by each category.

Last, we used the permeability matrix to identify LCPs for jaguar movements using the "Cost Path" tool of ArcGIS 9.3 (ESRI, Redlands, California, USA). LCPs are represented as lines that result from cell selection for the shortest distance and the lowest costs of movements in the landscape permeability matrix. The LCPs can be interpreted as potential corridors (LaRue and Nielsen 2008; Cushman et al. 2009).

For LCPs, we selected as movement origins each of the jaguar records from the SMO, and used the potential habitat patches identified from maximum entropy modeling as destinations. We calculated the length of each route, and termed routes $\geq 20 \mathrm{~km}$ (maximum distance traveled regularly by a jaguar; Sollmann et al. 2011) dispersal routes. In contrast, we classified shorter routes $(0.5 \mathrm{~km}$ to $19.9 \mathrm{~km}$ ) as daily travel routes (Schaller and Crawshaw 1980). We interpreted the resultant biological routes regionally from north to south using each Mexican state as a separate region. This regionalization was necessary because all Mexican states are independent administrative units within the country, and therefore each state has its own administrative policy. Finally we described the relationship between route type and habitat patches relative to their location with respect to natural protected areas and Priority Terrestrial Regions within the study area.

\section{Results}

We obtained and classified 68 jaguar locations (Rosas-Rosas et al. 2002; Villordo-Galván et al. 2010; Hernández Saint-Martin et al 2013; Hernández Saint-Martin et al. 2014; Martinez-Calderas, per. comm.) that met the Class I credibility criterion of Tewes and Everett (1986; Figure 3). Maximum entropy modeling indicated that distribution of jaguars in the SMO was most strongly associated with slope and land use-vegetation type (Table 1). The best supported model contained slope and land usevegetation type and fit data well ( $\mathrm{AUC}=0.881 ; \mathrm{SE}=0.056$; Concordance $=79 \%$ ); slope accounted for $53 \%$ of the proportional variance in the model and likelihood of jaguar presence was $>0.70$ in areas with slope $<$ approximately $9^{\circ}$, then decreased rapidly until likelihood of presence was $<0.50$ with slopes $>11^{\circ}$. Land use-vegetation type accounted for $47 \%$ of the proportional variance in the model; presence of jaguar was most strongly associated with tropical forest (Likelihood > 0.70; Figure 4). Collectively, jaguar presence was most likely in tropical and oak forests with moderate slope.

We identified 581 patches of suitable habitat ranging from $1 \mathrm{~km}^{2}$ to $740.5 \mathrm{~km}^{2}$ which totaled $23 \%$ of our evaluation area. Of these, 3 were $>100 \mathrm{~km}^{2}$ and thus met the criteria for fundamental patches. The remaining (578) patches were classified as stepping-stone (Figure 5). Of our evaluation landscape, $1 \%$ was classed as fundamental patches and $99 \%$ as stepping-stones (Figure 5). 


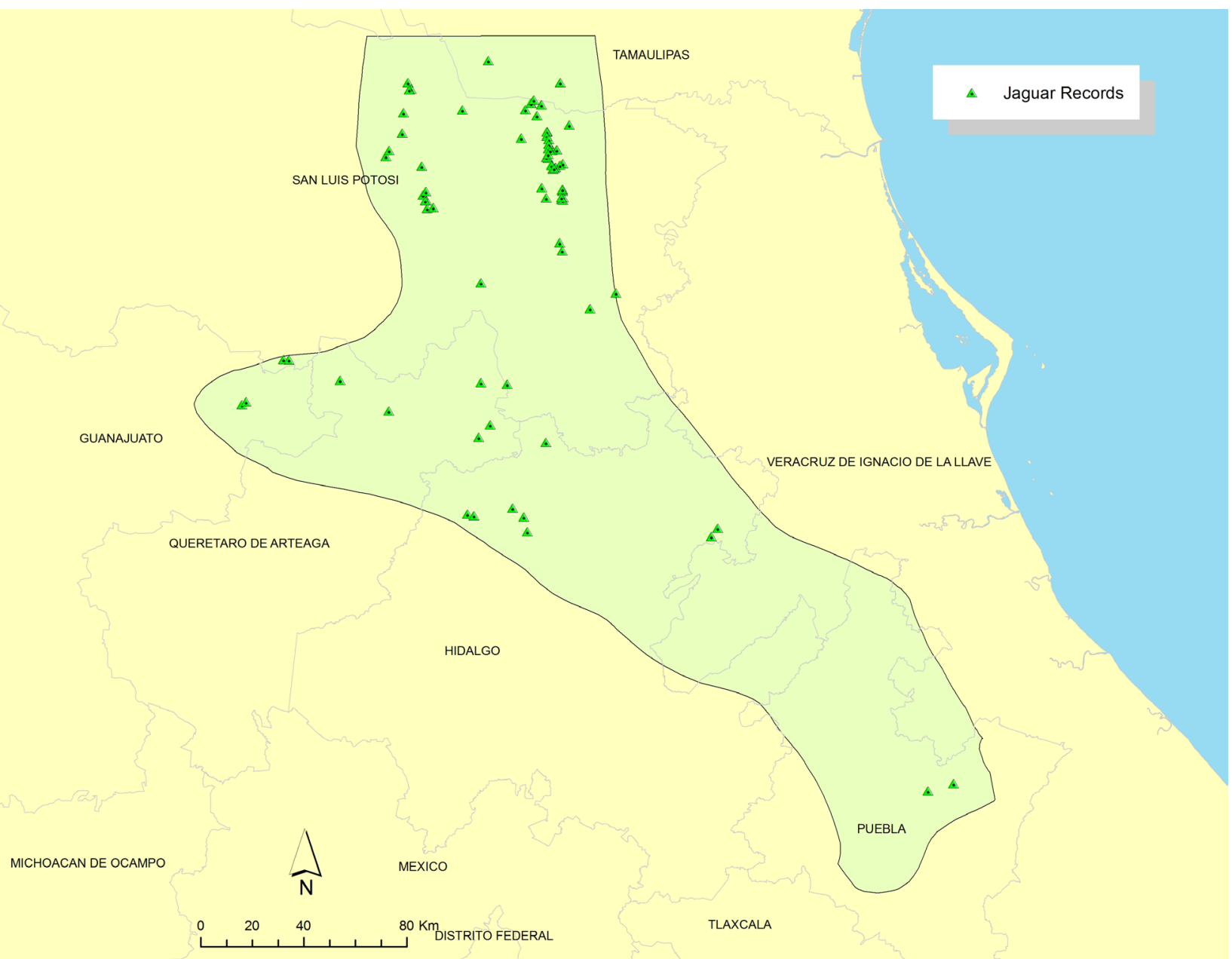

Figure 3. Verified photographic records of jaguars in the Sierra Madre Oriental, 1999-2011.

Table 1. Area-under-curve, SE, probability that models differed from the highest AUC model, and percent successful classification of maximum entropy models of jaguar presence in the Sierra Madre Oriental. Presented are the highest AUC 1-6 variable models.

\begin{tabular}{|c|c|c|c|c|}
\hline Model & AUC & SE & Concordance(\%) & $P$ \\
\hline $\mathrm{S}, \mathrm{L}, \mathrm{R}, \mathrm{W}, \mathrm{E}, \mathrm{Pa}$ & 0.906 & 0.049 & 82.5 & 0.946 \\
\hline$S, L, R, W, E$ & 0.908 & 0.050 & 82.5 & --- \\
\hline$S, L, R, W$ & 0.892 & 0.056 & 82.5 & 0.600 \\
\hline$S, L, R$ & 0.881 & 0.056 & 78.2 & 0.312 \\
\hline$S, L$ & 0.882 & 0.052 & 79.4 & 0.314 \\
\hline S & 0.819 & 0.046 & 73.0 & 0.001 \\
\hline
\end{tabular}

a $\mathrm{S}=$ slope; $\mathrm{L}=$ landuse-vegetation type; $\mathrm{R}=$ distance to road; $\mathrm{W}=$ distance to water $\mathrm{E}=$ elevation; $\mathrm{P}=$ human population density.

We surveyed 9 jaguar researchers from universities and research centers in Latin America for our AHP analysis. Results of surveys suggested that areas with population densities $<7$ inhabitants $/ \mathrm{km}^{2}$; with slopes from $0-3^{\circ}$; elevations of $>1000 \mathrm{~m}$; presence of permanent water within $2 \mathrm{~km}$; and $>$ $16 \mathrm{~km}$ from roads were the most likely to be used by jaguar. Further, tropical forests, oak forests, and tropical deciduous forests were considered the most suitable vegetation types for jaguar in the 
Table 2. Weights of relative importance for landscape variables (distance to water, distance to roads, elevation, slope, human density, and land use-vegetation type) used in the development of the permeability matrix for jaguar movements in the Sierra Madre Oriental, eastern México.

\begin{tabular}{|c|c|c|c|c|}
\hline Variable & IC & Aattribute & Weight & Normalized Weight \\
\hline \multirow[t]{5}{*}{ Distance to water (km) } & 0.06 & $0-2$ & 0.582 & 1 \\
\hline & & $2-4$ & 0.216 & 0.371 \\
\hline & & $4-8$ & 0.128 & 0.22 \\
\hline & & $8-16$ & 0.047 & 0.081 \\
\hline & & $>16$ & 0.027 & 0.046 \\
\hline \multirow[t]{5}{*}{ Distance to road (km) } & 0.05 & $0-2$ & 0.033 & 0.065 \\
\hline & & $2-4$ & 0.063 & 0.124 \\
\hline & & $4-8$ & 0.129 & 0.252 \\
\hline & & $8-16$ & 0.261 & 0.51 \\
\hline & & $>16$ & 0.513 & 1 \\
\hline \multirow[t]{4}{*}{ Elevation (m) } & 0.06 & $16-1000$ & 0.613 & 1 \\
\hline & & $1000-2000$ & 0.208 & 0.34 \\
\hline & & $2000-3000$ & 0.089 & 0.145 \\
\hline & & $3000-3169$ & 0.089 & 0.145 \\
\hline \multirow[t]{4}{*}{ Slope $\left({ }^{\circ}\right)$} & 0.07 & $0-3$ & 0.577 & 1 \\
\hline & & $3-17$ & 0.301 & 0.522 \\
\hline & & $17-45$ & 0.082 & 0.142 \\
\hline & & $>45$ & 0.039 & 0.068 \\
\hline \multirow{4}{*}{$\begin{array}{l}\text { Human population } \\
\text { density (No. of people/ } \\
\text { km²) }^{2}\end{array}$} & 0.09 & $0-7$ & 0.647 & 1 \\
\hline & & $7-14$ & 0.243 & 0.376 \\
\hline & & $14-28$ & 0.059 & 0.092 \\
\hline & & $>28$ & 0.051 & 0.079 \\
\hline
\end{tabular}

study area (Table 2). Respondents considered the type of land use- vegetation and the human population density to be the most important landscape characteristics associated with jaguar presence (Table 3).

The resultant permeability matrix indicated that approximately $49 \%$ and $3 \%$ of the SMO constituted areas of medium and low resistance to jaguar movements, respectively (Figure 6). The remaining $48 \%$ was characterized by attributes that probably represented a barrier for jaguar movements. Most of the areas of higher resistance and therefore the higher cost areas for jaguar movements were located in the western portion of the SMO (Figure 6).

Results of the LCP analysis showed 61 dispersal routes totaling $>2,000 \mathrm{~km}$, and $>200$ travel routes (Figure 7). The largest number of both route types was in Hidalgo (Table 4). Potentially significant movement corridors for jaguar in the SMO included:

1. In the northern region of our study area, routes originate in habitat patches in Queretaro Jalpan de Serra, Landa de Matamoros and Arroyo Seco in Querétaro and reach Tepehuacán de Guerrero and Jacala de Ledezma in San Luis Potosí and Hidalgo, respectively. A fourth route originates in San Ciro de Acosta and Lagunillas in San Luis Potosi and reaches Xichú municipality in Guanajuato. 

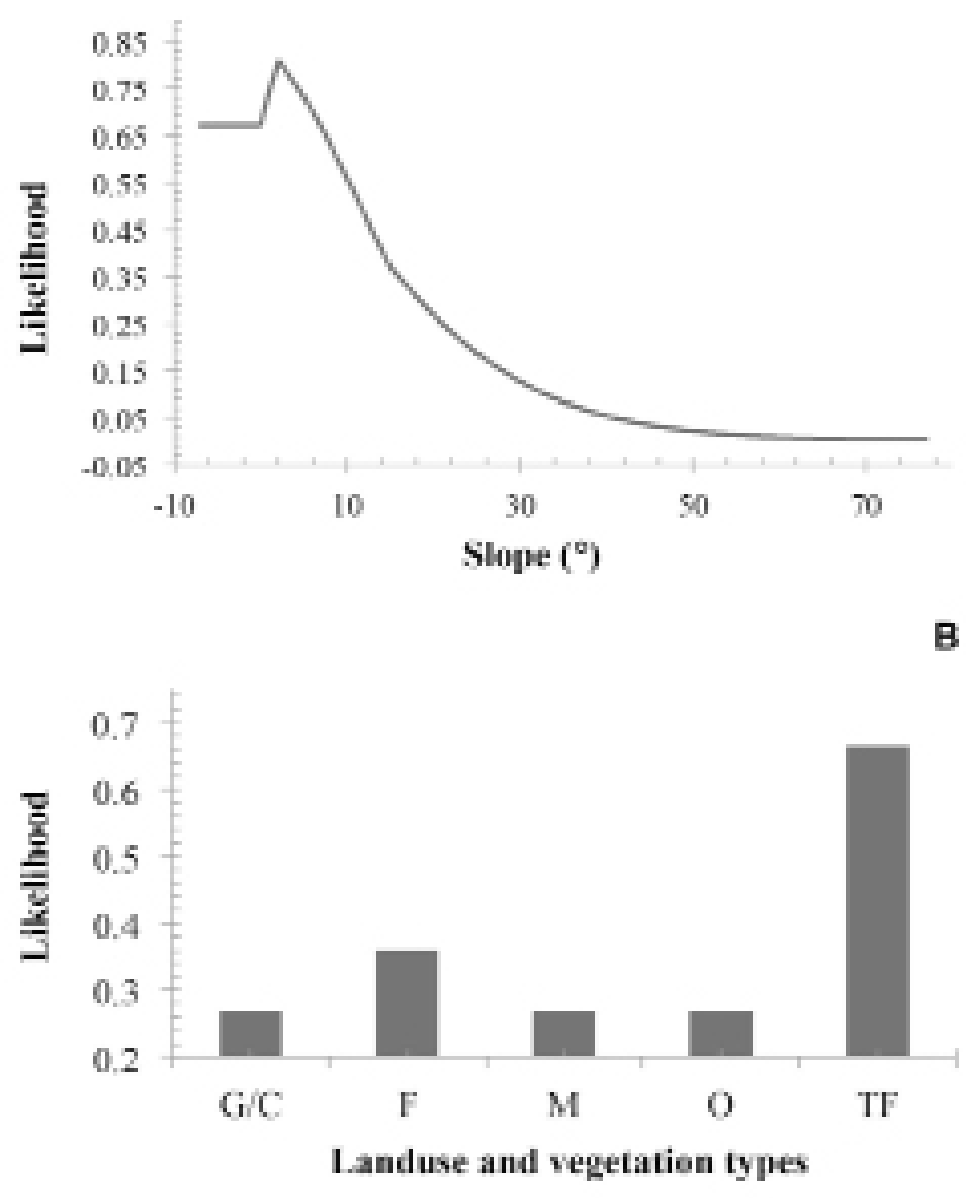

Figure 4. Likelihood of jaguar presence as a function of slope (A) and landuse-vegetation type (B) in the Sierra Madre Oriental of México. Landuse and vegetation types include: $\mathrm{G} / \mathrm{C}=$ grassland/cattle; $\mathrm{F}=$ oak forest; $\mathrm{M}=$ matorral; $\mathrm{O}=$ others (urban areas and human settlements); and TF = Tropical deciduous forest.

2. In the middle region, numerous dispersal routes originate in Hidalgo (e. g. in localities including Pisaflores, Chapulhuacan, Tlanchinol, Yahualica, San Felipe Orizatlan, Hujutla de Reyes, and Atlapexco, Huatla) providing for movement throughout Hidalgo and into other states, including a route towards Veracruz that passes through through Chiconamel.

Table 3. Relative importance of landscape variables based on an expert opinion analysis of how they may influence movements of jaguars in the Sierra Madre Oriental. IC $=0.07$ for relative importance weights (IC measures the proportion of the consistency of judgments and the desired value must be $<1$; Malczewski 2004)).

\begin{tabular}{|c|c|c|}
\hline Landscape Attribute & Weight & Normalized Weigth \\
\hline Landuse-vegetation type & 0.2484 & 1.000 \\
\hline Human population density & 0.4744 & 0.524 \\
\hline Distance to road & 0.0284 & 0.259 \\
\hline Elevation & 0.0767 & 0.162 \\
\hline Distance to water & 0.0493 & 0.104 \\
\hline Slope & 0.1229 & 0.060 \\
\hline
\end{tabular}

*IC: Measures the proportion of the consistency of judgments and the desired value must be $<1$. 


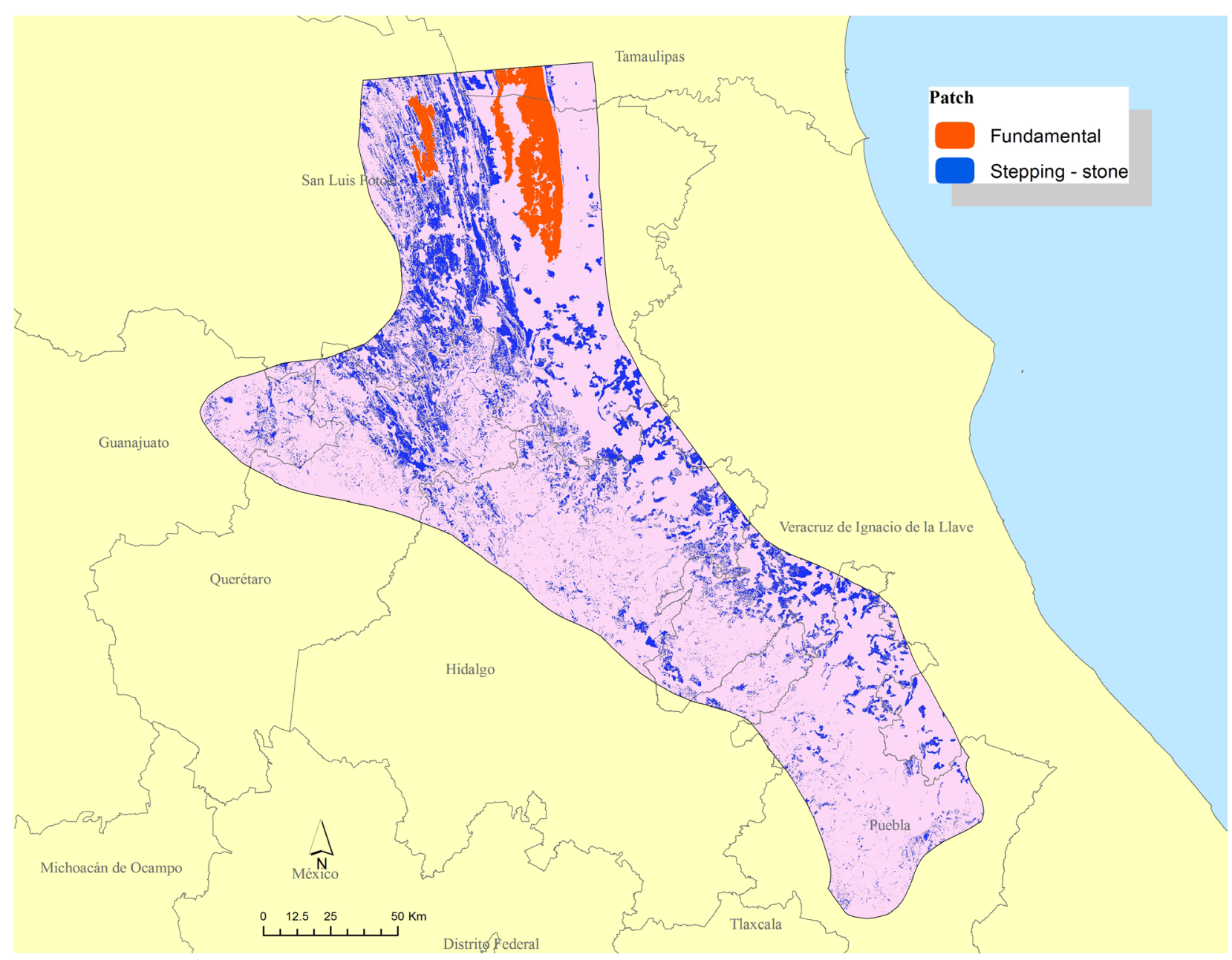

Figure 5. Fundamental $\left(\geq 100 \mathrm{~km}^{2}\right)$ and stepping-stone patches of suitable habitat for jaguars in the Sierra Madre Oriental.

3. In the south, two potential dispersal routes interconnected by numerous travel routes could function as major jaguar corridors to northern areas of the state of Puebla. These corridors may be particularly important for jaguar dispersal south to other jaguar populations in southern México (Figure 8). The Sierra Madre Oriental corridors originate in the state of Veracruz through

Table 4. Number and total length of dispersal and travel routes determined from Least Cost Path analysis for jaguar movements in the southern Sierra Madre Oriental, México, by state.

Dispersal

\begin{tabular}{lcccc}
\multicolumn{1}{c}{ Region } & Number & Length $(\mathbf{k m})$ & Number & Length (km) \\
\hline Tamaulipas & 0 & 0 & 2 & 19.7 \\
San Luis Potosí & 14 & 417.2 & 131 & 1085.9 \\
Guanajuato & 2 & 47.2 & 3 & 37.5 \\
Querétaro & 4 & 118.3 & 32 & 282.5 \\
Hidalgo & 19 & 697.2 & 40 & 372.7 \\
Puebla & 15 & 540.2 & 27 & 320.4 \\
Veracruz & 7 & 242.1 & 26 & 213.0 \\
& & & & 2331.7 \\
Total & 61 & 2062.2 & 261 & \\
\hline
\end{tabular}

Travel 
the Cuenca Hidrográfica del Río Necaxa including municipalities of Z. Mena, Venustiano Carranza, Xicotepec and the priority región of Cuetzalan through minicipalties such as Tuzamapa de Galeana, Jonotla and Zoquiapan.

\section{Discussion}

Our regional analysis of the southern SMO identified habitat patches sufficient to maintain multiple populations of jaguars (fundamental patches), as well as numerous smaller habitat patches that provided the resources necessary to facilitate movements of jaguars (stepping-stones). These results affirm the importance of the SMO for the conservation of jaguars in México in both the short and long term (Grigione et al. 2009; Rodríguez-Soto et al. 2011). Although the fundamental patches we identified were separated by relatively long distances (Figure 7) with respect to the movement patterns of the jaguar, this was mitigated by the number and distribution of stepping-stones as intermediates that provided connectivity among the fundamental patches. Because of the number, function, and importance of the stepping-stone patches, the fundamental patches were likely not isolated despite the relatively high degree of fragmentation. Stepping-stones help maintain the populations that reside in the fundamental patches by facilitating the flow of individuals and serving as forage and cover stations during dispersal (Bennett et al. 2004).

The biological corridor concept has evolved into a more comprehensive paradigm from its origin of simple linear features (Bennett and Mulongoy 2006). Currently, corridors are viewed as a mosaic of land use types and other landscape features that allow connectivity among patches of suitable habitat across the landscape (Bennett and Mulongoy 2006). Understanding the role of the landscape matrix as habitat for wildlife, particularly in fragmented landscapes such as the SMO, is important because the distribution of habitat components influences the movement patterns of the target species (Riley et al. 2003). Our results corroborated the presence of suitable habitat for the jaguar where jaguars have been located and studied in the states of Tamaulipas, San Luis Potosi, and Querétaro (Ortega-Huerta and Medley 1999; Bravo and González 2006; Villordo-Galván et al. 2010). Moreover, our model predictions indicated several additional areas with high likelihood of suitable habitat in little studied areas, including Veracruz, Hidalgo, and Puebla. A priority should be to survey these areas for jaguar presence, and to analyze with greater detail the potential connectivity between these patches and the known populations of jaguar that occur to the south.

Our permeability matrix indicated a high proportion (48\%) of areas with high resistance to jaguar movement, likely due to the degradation of the landscape, particularly changes in land use to agriculture and cattle ranching (Williams-Linera et al. 2003; Rivera et al. 2010). Ongoing development results in only remnants of original habitat being available for jaguars, and reaffirms the need to protect and restore habitat that connects core jaguar populations (Villordo-Galván et al. 2010; Ávila Nájera et al. 2011). However, despite high disturbance and fragmentation in this region of México, our results and previous studies indicate that biodiversity is still high in the Huasteca Region of San Luis Potosí (Villordo-Galván et al. 2010). In addition, jaguars are resident in this region of San Luis Potosí and likely juveniles or adults are dispersing towards southern areas through the proposed corridors (Villordo-Galván et al. 2010; Ávila Nájera et al. 2011).

Moreover, it is possible that areas classified as having high resistance to jaguar movements could result simply from the characteristics of the habitat variables proposed by experts from other countries exceeding the standards of suitability for jaguars in México. This would result in an apparent lower level of habitat suitability in the SMO than is actually present. This could also have occurred when the Jaguar Conservation Units were delineated by Sanderson et al. (2002), which declared the SMO as likely isolated from other jaguar populations in México and therefore as an area of secondary importance for long-term jaguar conservation. This conclusion was made despite a 


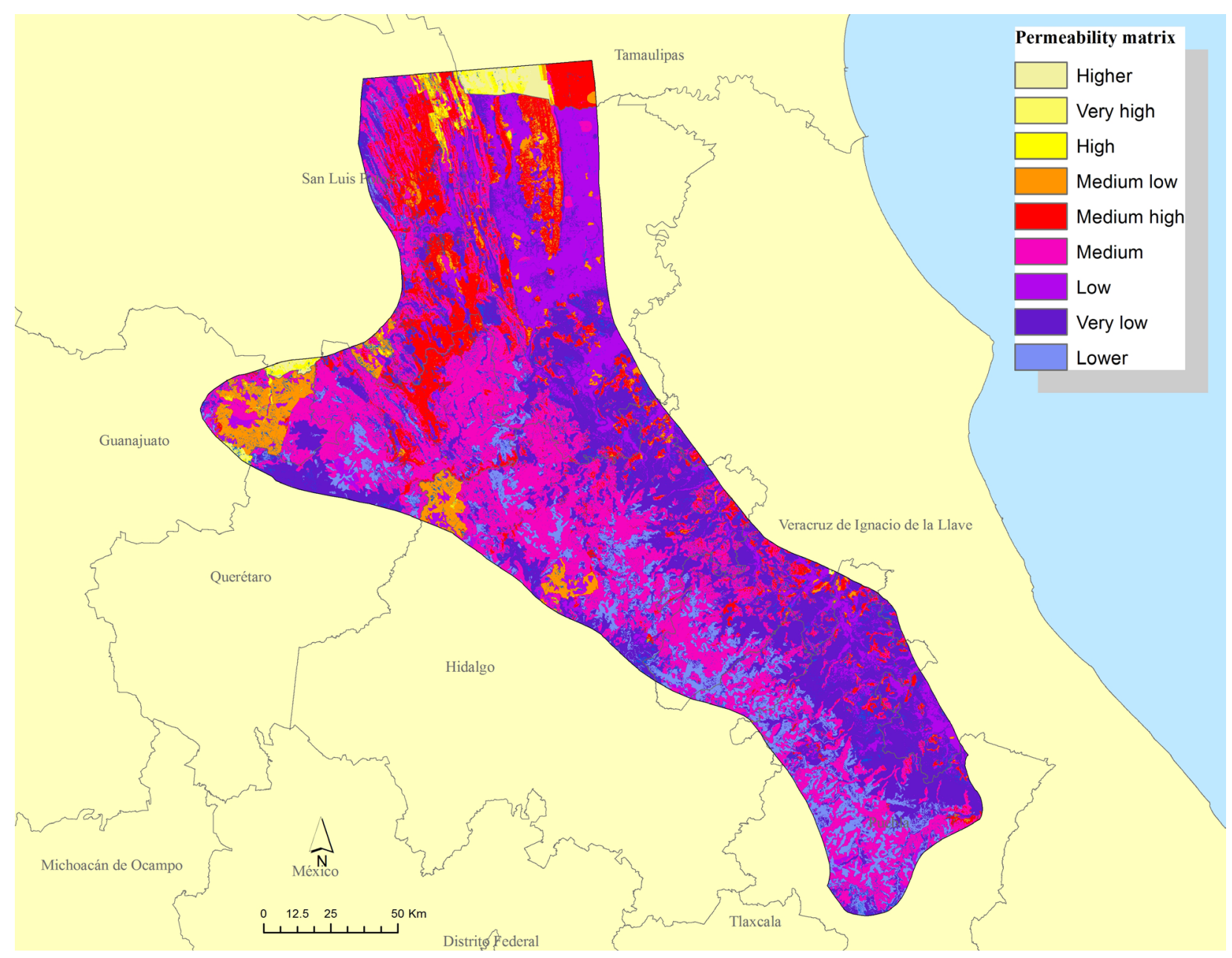

Figure 6. Permeability matrix showing resistance of the landscape for movements of jaguars.

lack (at that time) of recent field surveys, and was likely premature. A similar case was presented by Morrison et al. (2012). Therefore, it is important to continue monitoring studies to better understand the current condition of the jaguar habitat and movement patterns throughout their range in México.

In our evaluation we analyzed the suitability of the SMO to provide corridors for movements of jaguars within the SMO and among other regions. The routes described were based on the best available data and knowledge, although they require further validation in field. With respect to existing landscape policy in the SMO, Comisión Nacional para el Conocimiento y Uso de la Biodiversidad (CONABIO; http://www.conabio.gob.mx) identified 4 Priority Terrestrial Regions (RTP) in our evaluation area. Three of these - the Sierra del Abra Tanchipa, Sierra GordaRio Moctezuma, and Bosque Mesofilos de la Sierra Madre Oriental - are postulated to act as biological corridors, whereas the fourth region (RTP-Cuetzalan) had no information to support this biological function (CONABIO; Fig 1). Our results confirm the biological functions of three of the four areas defined by $C O N A B I O$, while providing further information on the function of the RTP-Cuetzalan. We identified several travel or dispersal routes which converged or originated in this RTP, providing potential routes of dispersal for jaguars into the Sierra Norte de Puebla. For this reason, the RTP-Cuetzalan is important for connectivity not only for the jaguar but also for other species that inhabit this region. Consequently, we recommend that the RTP-Cuetzalan be considered for designation as a Natural Protected Area, because it still retains significant high 


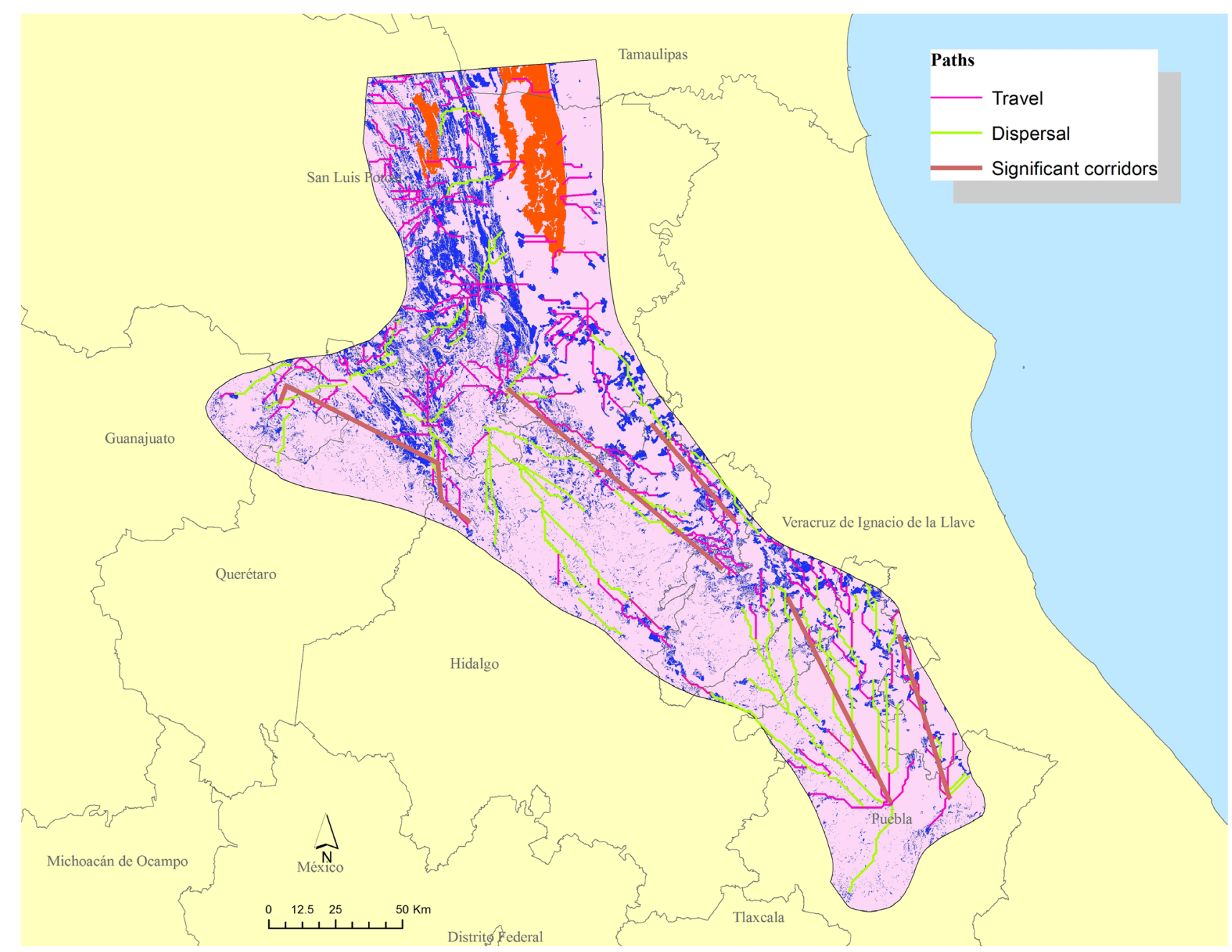
paths.

Figure 7. Potential biological corridors for jaguar in the Sierra Madre Oriental of México, including locations of dispersal and travel

quality habitat for wildlife which facilitates its ability to support individuals dispersing to other areas, as well as providing for many resident species.

In addition to the existing data on each RTP, vertebrate studies in the SMO further indicate the presence of the main prey of the jaguar (Núñez et al. 2000; Rosas-Rosas et al. 2008) in San Luis Potosí (Ávila-Nájera et al. 2011; Rueda et al. 2013), Hidalgo (Sánchez-Rojas et al. 2009), and Puebla (VillarrealEspino-Barros et al. 2008; Bravo et al. 2010). Because the distribution and movements of jaguars depend largely on the presence of food, these records further indicate the potential of the SMO to support the long-term needs and movements of the jaguar (González and Miller 2002).

Last, the accuracy of model predictions such as our maximum entropy results and permeability matrix are determined by the quality of data. We used an appropriate number of presence records and landscape variables that functionally relate to jaguar movements, which resulted in a good model based on model fit criteria (Guisan et al. 2006; Anderson and Gonzalez 2011). However, it is also necessary to consider the reliability of the records (Mateo et al. 2011). Despite limiting our modeling to only highly reliable jaguar records within the region, and thus limiting our overall sample size, the predictive ability of our preferred maximum entropy model was good, possibly due to the precise demarcation of the study area (Soberón 2010) and the reliability of the records that we used. In addition, we consider at least one record in five of the seven States studied (i. e. $70 \%$ of the area contained information for input into models). 


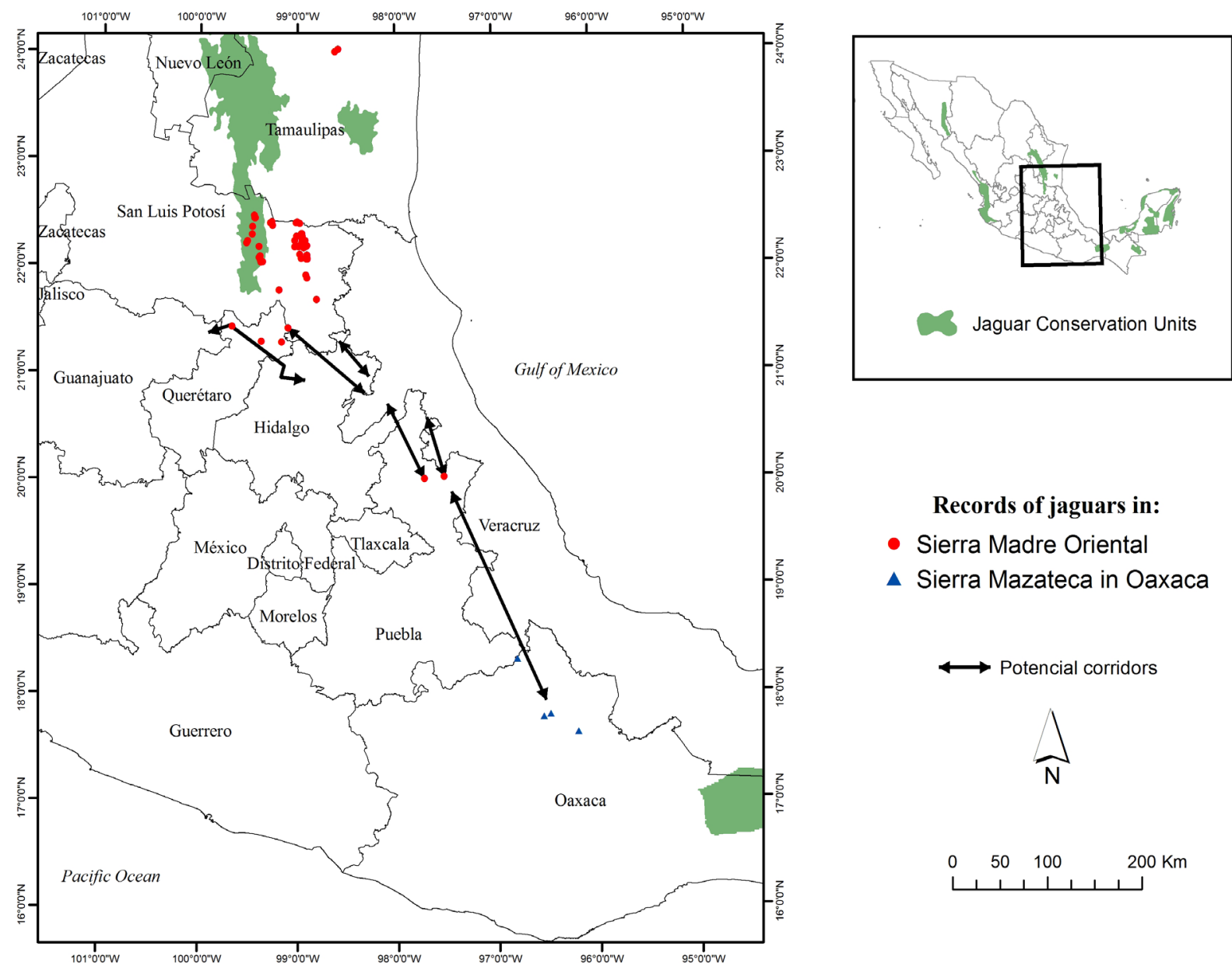

Figure 8. Biological corridors that allow connectivity of the SMO to southern regions of the state of Puebla, with further possibilities of connection to jaguar populations of northeastern Oaxaca.

Further, the landscape attributes we found best associated with suitable habitat for the jaguar were also frequently identified in the literature (Quigley and Crawshaw 1992; Monroy Vilchis et al. 2008; Conde et al. 2010; Villordo-Galván et al. 2010; Colchero et al. 2011). Habitat quality and distribution of jaguars is most frequently associated with specific vegetation types and land use (Monroy-Vilchis et al. 2008; Rosas-Rosas and Valdez 2010; Colchero et al. 2011). The variables we modeled thus allowed us to locate specific areas with habitat features highly conducive to the presence of jaguars.

Implications. Biological corridors of the SMO initiate at fundamental patches in the States of Tamaulipas and San Luis Potosí, with continuity towards the State of Queretaro. In Queretaro, historic and present reports of jaguar presence and the presence of primary prey suggests that suitable habitat conditions exist to allow jaguars to meet their basic requirements (Téllez and López 1995). Although there are no historical or recent records of jaguars in Hidalgo, we identified routes that connect directly with the state of Puebla, with further possibilities of connection to northeastern Oaxaca where the presence of the jaguar was recently documented (Figures 7 and 8; Briones-Salas et al. 2012).

In Puebla, routes apparently diverge and may indicate the presence of a barrier (Figure 6). However, the more westerly route is promising because of proximity among multiple small fragments of habitat, presence of multiple travel routes, and proximity to the Necaxa River hydrographic basin. The Necaxa River watershed is important because of its similarity to the Sierra del Abra Tanchipa in San Luis Potosi. Like the Sierra del Abra Tanchipa, which is also surrounded 
by fragmented landscapes of secondary vegetation and agricultural and livestock areas, this region has a core of habitat conducive to prey and vegetation coverage that can provide suitable habitat for jaguars and feasibly allow dispersal (as well as support permanent populations) in these highly fragmented landscapes.

We conclude that the SMO provides multiple biological corridors for connectivity with more southern populations of jaguar in México (Figure 8). Based on this, we recommend development of management strategies to facilitate exchange of individuals from the SMO with other known jaguar populations in southern states (e. g. Oaxaca, Tabasco, Guerrero). Principal strategies may focus on habitat management of fundamental patches and habitat restoration between or around stepping-stones. The quality of the habitat patch is important because it determines availability of prey. Finally we suggest continued field research in order to seasonally monitor prey populations, jaguar presence, and movements. Working with local communities to improve habitat, enhance conservation of landscapes, and conduct educational programs on minimizing human-jaguar conflicts is also needed.

This information can also help to identify areas where management policies should be revised and also where future development should be reviewed and possibly minimized to mitigate any potential negative effects to critical patches or corridors. Because corridors overlap multiple jurisdictions, it is also important to coordinate local and regional conservation efforts so that individual actions can be linked across larger regions to form cohesive connectivity networks.

\section{Acknowledgements}

We are grateful to the National Council of Science and Technology (CONACYT-Mexico), Grant No. 253033 awarded to Master Student G. Dueñas Lopez and all researchers, students and field assistants who took part in this research.

\section{Resumen}

Introducción: Los jaguares (Panthera onca) son depredadores ápexy son susceptibles a los efectos de la fragmentación. Algunas de sus poblaciones están consideradas en proceso de aislamiento en México donde esta enlistado como en peligro de extinción. El principal objetivo fue evaluar la conectividad disponible de La Sierra Madre Oriental (SMO) hacia el sur de México.

Metodología: Se determinaron las Rutas de Menor Costo para el jaguar entre parches de hábitat dentro de la SMO. Se usaron registros recientes de presencia y mediante el algoritmo de modelaje de máxima entropía (Maxent) se identificaron parches de hábitat potencial. Se usó el Proceso Jerárquico Analítico para generar valores (permeabilidad del paisaje) y a su vez crear una matriz de resistencia para los movimientos del jaguar usando una Evaluación-MultiCriterio con una combinación lineal ponderada. Finalmente se modelaron las Rutas de Menor Costo para movimientos locales y de dispersión del jaguar.

Resultados: Se identificaron 581 parches con hábitat potencial altamente adecuado para el jaguar. Donde tres de estos son $>100 \mathrm{~km}^{2}$, y son considerados de tipo fundamental (capaces de soportar una población viable de jaguares). La matriz de resistencia se compone en $3 \%$ de zonas con bajo costo, 49\% de zonas con costo medio para los movimientos del jaguar. El análisis de Rutas de Menor Costo mostró 61 rutas de dispersión totalizando > 2,000 km y > 200 rutas de movimiento, donde el estado de Hidalgo presenta el mayor número de rutas de ambos tipos. También se identificaron 5 potenciales corredores para el jaguar dentro de la SMO y hacia el sur de las poblaciones de jaguar en México.

Discusión y conclusiones: Se determinó que la SMO posee hábitat significativo y con múltiples corredores biológicos para la conectividad de las poblaciones del jaguar de esta región con las del sur de México. Basado en los resultados se recomienda el desarrollo de estrategias de manejo que puedan facilitar el intercambio de individuos de la SMO con otras poblaciones en el sur de México (Oaxaca, Tabasco, Guerrero). Las principales estrategias se pueden enfocar en manejo de hábitat en los parches fundamentales y restauración de hábitat entre y alrededor de las "piedras de paso". Promover la conectividad entre los parches de hábitat y las poblaciones de jaguar que habitan en la SMO incrementará el potencial de biodiversidad y la conservación de esta región a largo plazo.

Palabras clave: Biodiversidad, corredores, fragmentación de hábitat, jaguar, rutas de menor costo, movimientos. 


\section{References}

Anderson, R. P., And I. Gonzalez, JR. 2011. Species-specific tuning increases robustness to sampling bias in models of species distributions: An implementation with Maxent. Ecological Modelling 222:2796-2811.

Ávila-Nájera, D. M., O. C. Rosas-Rosas, L. A. Tarango-Arámbula, J. F. Martínez-Montoya, and E. SantoyoBRITo. 2011. Conocimiento, uso y valor cultural de seis presas del jaguar (Panthera onca) y su relación con éste, en San Nicolás de los Montes, San Luis Potosí, México. Revista Mexicana de Biodiversidad 82:1020-1028.

Baldwin, R. A., AND L. C. Bender. 2008. Den-site characteristics of black bears in Rocky Mountain National Park, Colorado. The Journal of Wildlife Management 72:1717-1724.

Bennett, A. F. 2004. Enlazando el paisaje: el papel de los corredores y la conectividad en la conservación de la vida silvestre. IUCN-the World Conservation Union. San José, Costa Rica.

Bennett, G., And K. J. Mulongoy. 2006. Review of experience with ecological networks, corridors and buffer zones. Secretariat of the Convention on Biological Diversity. Montreal, Canada.

Bravo, O. E. R., S. S. Brault, and C. H. Santín. 2010. Nuevo registro del Ocelote (Leopardus pardalis) para el estado de Puebla. Therya 1:91.

Bravo, O. E. R., AND C. A. Lopez. 2006. Determinación de áreas críticas para la supervivencia del jaguar en la Sierra Madre Oriental. Pp. 41-50 in Conservación y manejo del jaguar en México estudios de caso y perspectiva (Ceballos, G., C. Chávez, R. List, and H. Zarza, eds.). Fondo de Cultura Económica - Universidad Nacional Autónoma de México - Wildlife Conservation Society- CONABIO. Ciudad de México, México.

Briones-Salas, M., M. C. Lavariega, and I. Lira-Torres. 2012. Distribución actual y potencial del jaguar (Panthera onca) en Oaxaca, México. Revista Mexicana de Biodiversidad 83:246-257.

Bunn, A. G., D. L. Urban, And T.H. Keitt. 2000. Landscape connectivity: A conservation application of graph theory. Journal of Environmental Management 59:265-278.

Colchero, F., D. A. Conde, C. Manterola, C. Chávez, A. Rivera, and G. Ceballos. 2011. Jaguars on the move: modeling movement to mitigate fragmentation from road expansion in the Mayan Forest. Animal Conservation 14:158-166.

Conde, D. A., F. Colchero, H. Zarza, N. L. Christensen, Jr, J. O. Sexton, C. Manterola, C. Chávez, A. Rivera, D. Azuara, and G Ceballos. 2010. Sex matters: Modeling male and female habitat differences for jaguar conservation. Biological Conservation 143:1980-1988.

Cramer, P. C., And K. M. Portier. 2001. Modeling Florida panther movements in response to human attributes of the landscape and ecological settings. Ecological Modelling 140: 51-80.

Cushman, S. A., K. S. McKelevey, and M. K. Schwartz. 2009. Use of empirically derived source-destination models to map regional conservation corridors. Conservation Biology 23:368-376.

Dickson, B. G., J. S. Jenness, ANd P. Beier. 2005. Influence of vegetation, topography, and roads on cougar movement In Southern California. The Journal of Wildlife Management 69:264-276.

Dixon, J. D., M. K. Olı, M. C. Wooten, T. H. Eason, J. W. McCown, and D. Paetkau. 2006. Effectiveness of a regional corridor in connecting two Florida black bear populations. Conservation Biology 20:155162.

EAstman, J. R. 2004. IDRISI Kilimanjaro, guía para SIG y procesamiento de imágenes. Labs Clark University. Worcester, EE. UU.

Fielding, A. H., ANd J. F. Bell. 1997. A review of methods for the assessment of prediction errors in conservation presence/absence models. Environmental Conservation 24:38-49.

González, C. A. L., And B. J. Miller. 2002. Do jaguars (Panthera onca) depend on large prey? Western North American Naturalist 62:218-222. 
Grigione, M. M., K. Menke, C. López-González, R. List, A. Banda, J. Carrera, R. Carrera, A. J. Giordano, J. Morrison, ANd M. Sternberg. 2009. Identifying potential conservation areas for felids in the USA and México: integrating reliable knowledge across an international border. Oryx 43:78-86.

Guisan, A., O. Broennimann, R. Engler, M. Vust, N. G. Yoccoz, A. Lehmann, and N. E. Zimmermann. 2006. Using niche-based models to improve the sampling of rare species. Conservation Biology 20:501-511.

Hernández-SaintMartín, A. D., O. C. Rosas-Rosas, J. Palacio-Núnez, L. A. Tarango-Arámbula, F. ClementeSÁnchez, ANd A. L. Hoogesteijn. 2013. Activity patterns of jaguars, puma and their potential prey in San Luis Potosi, Mexico. Acta Zoológica Mexicana 29:520-533.

Hernández-SaintMartín, A. D., O. C. Rosas-Rosas, J. Palacio-Núñez, L. A. Tarango-Arámbula, F. ClementeSánCHEZ, ANd A. L. Hoogesteisn. 2014. Food habits of jaguar and puma in a protected area and adjacent fragmented landscape of Northeastern Mexico. Natural Areas Journal 35:308-317.

Hosmer, D. W., And S. Lemeshow. 1989. Applied logistic regression. Second edition. John Wiley and Sons. New York, U.S.A.

INEGI (Instituto Nacional de Estadística y Geografía). 2011. Cartas geográficas de clima, suelo y precipitaciones, Escalas 1: 100,000 y 1: 250,000, Instituto Nacional de Estadística, Geografía e Informática. Ciudad de México, México.

LaRue, M.A., and C. K. Nielsen. 2008. Modelling potential dispersal corridors for cougars in midwestern North America using least-cost path methods. Ecological Modelling 212:372-381.

Malczewskı, J. 2004. GIS-based land-use suitability analysis: a critical overview. Progress in Planning 62:365.

Mateo, R. G., A. M. Felicísımo, And J. Muñoz. 2011. Modelos de distribución de especies: Una revisión sintética. Revista Chilena de Historia Natural 84:217-240.

Monroy-Vilchis, O., O. Sánchez, U. Aguilera-Reyes, P. Suárez, and V. Urios. 2008. Jaguar (Panther aonca) in the state of México. The Southwestern Naturalist 53:533-537.

Morrison, M. L., B. A. Collier, H. A. Mathewson, J. E. Groce, And R. N. Wilkins. 2012. The prevailing paradigm as a hindrance to conservation. Wildlife Society Bulletin, 36:408-414.

Núñez-Pérez, R. 2011. Estimating jaguar population density using camera-traps: a comparison with radiotelemetry estimates. Journal of Zoology 285: 39-45.

Núñez, R., B. MilleR, ANd F. Lindzey. 2000. Food habits of jaguars and pumas in Jalisco, México. Journal of Zoology 252: 373-379.

Ortega-Huerta, M. A., And K. E. Medley. 1999. Landscape analysis of jaguar (Panthera onca) habitat using sighting records in the Sierra de Tamaulipas, México. Environmental Conservation 26:257-269.

Ortega-Huerta, M. A., And A. T. Peterson. 2004. Modelling spatial patterns of biodiversity for conservation prioritization in North-eastern México. Diversity and Distributions 10:39-54.

Pearce, J., And S. Ferrier. 2000. Evaluating the predictive performance of habitat models developed using logistic regression. Ecological Modelling 133:225-245.

Phillips, S. J., R. P. Anderson, and R. E. Schapire. 2006. Maximum entropy modeling of species geographic distributions. Ecological Modelling 190:231-259.

Quigley, H. B., ANd P. G. Crawshaw, JR. 1992. A conservation plan for the jaguar Panthera onca in the Pantanal region of Brazil. Biological Conservation 61:149-157.

Rabinowitz, A., and K.A. Zeller. 2010. A range-wide model of landscape connectivity and conservation for the jaguar, Panthera onca. Biological Conservation 143:939-945.

Riley, S. P. D., R. M. Sauvajot, T. K. Fuller, E. C. York, D. A. Kamradt, C. Bromley, and R. K. Wayne. 2003. Effects of urbanization and habitat fragmentation on bobcats and coyotes in Southern California. Conservation Biology 17:566-576.

Rivera, N. A., G. G. Mendoza, J. F. Martínez, and C. C. Servin. 2010. Evaluación multicriterio y aptitud agroclimática del cultivo de caña de azúcar en la región de Huasteca (México). Revista CORPOICA. Ciencia y Tecnología Agropecuaria 11:144-154. 
Rodríguez-Soto, C., O. Monroy-Vilchis, L. Maiorano, L. Boitani, J. C. Faller, M. A. Briones, R. Núñez, O. C. Rosas-Rosas, G. Ceballos, and A. Falcuccl. 2011. Predicting potential distribution of the jaguar (Panthera onca) in México: identification of priority areas for conservation. Diversity and Distributions 17:350-361.

Rosas-Rosas, O. C., AND J. H. López-Soto. 2002. Distribución y estado de conservación del jaguar en Nuevo León, México. Pp. 379-392 in El jaguar en el nuevo milenio (Medellín, R., C. Equihua, C. Chetkiewicz, P. Crawshaw, A. Rabinowitz, K. Redford, J. Robinson, and E. Sanderson, eds.). Fondo de Cultura Económica-Universidad Nacional Autónoma de México- Wildlife Conservation Society. Ciudad de México. México.

Rosas-Rosas, O. C., L. C. Bender, And R. Valdez. 2008. Jaguar and puma predation on cattle calves in northeastern Sonora, México. Rangeland Ecology and Management 61:554-560.

Rosas-Rosas, O.C., L. C. Bender, and R. Valdez. 2010. Habitat correlates of jaguar kill-sites of cattle in northeastern Sonora, México. Human-Wildlife Interactions 4:103-111.

Rosas-Rosas, O. C., AND R. Valdez. 2010. The role of landowners in jaguar conservation in Sonora, México. Conservation Biology 24:366-371.

Rueda, P., G. D. Mendoza, D. Martínez, and O. C. Rosas-Rosas. 2013. Determination of the jaguar (Panthera onca) and puma (Puma concolor) diet in a tropical forest in San Luis Potosi, México. Journal of Applied Animal Research 41:1-6.

SAATY, T. L. 1980. The analytic hierarchy process: planning, priority setting, resources allocation. McGrawHill. New York, EE. UU.

Sánchez-Rojas, G., C. Aguilar-Miguel, and E. Hernández-Cid. 2009. Estudio poblacional y uso de hábitat por el venado cola blanca (Odocoileus virginianus) en un bosque templado de la Sierra de Pachuca, Hidalgo, México. Journal of Tropical Conservation Science 2:204-214.

Sahagún-Sánchez, F. J., H. Reyes-Hernández, J. L. Flores, and L. Chapa. 2011. Modelización de escenarios de cambio potencial en la vegetación y el uso de suelo en la Sierra Madre Oriental de San Luis Potosí, México. Journal of Latin American Geography. 10:65-86.

Sanderson, E. W., K. H. Redford, C. Chetkiewicz, R. A. Medellin, A. Rabinowitz, J. G. Robinson, and A. B. Taber. 2002. Planning to save a species: the jaguar as a model. Conservation Biology 16:58-72.

Schaller, G. B., ANd P. G. CRawshaw JR. 1980. Movement patterns of jaguar. Biotropica 210:161-168.

Semarnat (Secretaria de Medio Ambiente y Recursos Naturales). 2010. Norma Oficial Mexicana NOM-059SEMARNAT-2010, Protección ambiental-Especies nativas de México de flora y fauna silvestresCategorías de riesgo y especificaciones para su inclusión, exclusión o cambio-Lista de especies en riesgo. Diario Oficial de la Federación. Ciudad de México. México.

Seymour, K. L. 1989. Panthera onca. Mammalian Species 340:1-9

Soberón, J. M. 2010. Niche and area of distribution modeling: a population ecology perspective. Ecography 33:159-167.

Sollmann, R., M. M. Furtado, B. Gardner, H. Hofer, A. T. A. Jácomo, N. M. Tôrres, and L. Silveira. 2011. Improving density estimates for elusive carnivores: Accounting for sex-specific detection and movements using spatial capture-recapture models for jaguars in central Brazil. Biological Conservation 144:1017-1024.

Swets, J. A. 1988. Measuring the accuracy of diagnostic systems. Science 240:1285-1293.

Téllez, G., AND W. C. López. 1995. Panthera onca veraecrucis (Carnivora: Felidae) en Querétaro, México. Revista Mexicana de Mastozoología 1:73-75.

Tewes, M. E., And D. Everett. 1986. Status and distribution of the endangered ocelot and jaguarondi in Texas. Pp. 147-158 in Cats of the world: biology, conservation, and management (Mondolfi, E., S. D. Miller, and D. D. Everet, eds.). National Wildlife Federation. Washington, EE. UU.

Villarreal-Espino-Barros, O. A., L. E. Campos-Armendia, T. A. Castillo-Martínez, I. Cortes-Mena, F. X. PlataPérez, and G. D. Mendoza-Martínez. 2008. Composición botánica de la dieta del venado temazate 
rojo (Mazama temama), en la sierra nororiental del estado de Puebla. Universidad y Ciencia 24:183188.

Villordo-Galván, J.A., O. C. Rosas-Rosas, F. Clemente-Sánchez, J. F. Martínez-Montoya, L. A. Tarango-Arámbula, G. D. Mendoza-Martínez, M. D. Sánchez-Hermosillo, and L. C. Bender. 2010. The jaguar (Panthera onca) in San Luis Potosí, México. The Southwestern Naturalist 55:394-402.

Williams-Linera, G., A. Rowden, and A. C. Newton. 2003. Distribution and stand characteristics of relict populations of Mexican beech (Fagus grandifolia var. mexicana). Biological Conservation 109:27-36.

Summited: December 8, 2014

Review: March 30, 2015

Accepted: April 10, 2015

Associated editor: Rafael Reyna 
468 THERYA Vol.6(2):449-468 